\title{
The Natural Kingdom of God in Hobbes's Political Thought
}

\author{
Forthcoming in the History of European Ideas
}

\begin{abstract}
In Leviathan, Hobbes outlines the concept of the 'Kingdome of God by Nature' or 'Naturall Kingdome of God', terms rarely found in English texts at the time. This article traces the concept back to the Catechism of the Council of Trent (1566), which sets forth a threefold understanding of God's kingdom — the kingdoms of nature, grace, and glory — none of which refer to civil commonwealths on earth. Hobbes abandons this Catholic typology and transforms the concept of the natural kingdom of God to advance a claim often missed by his interpreters: Leviathan-states are the manifestation of a real, not metaphorical, kingdom of God. This argument plays a key role in Leviathan, which identifies the kingdom of God as the Christian doctrine most subject to abuse. Hobbes harshly criticizes Catholic and Presbyterian clergy for claiming to represent God's kingdom. This claim, he argues, comes with the subversive implication that the church possesses spiritual and temporal authority, and caused great turmoil during the English Civil War. As an alternative, Hobbes points to civil commonwealths as the manifestation of God's natural kingdom, which is the only form his kingdom currently takes.
\end{abstract}

\section{Keywords}

Catholic; Thomas Hobbes; kingdom of God; Leviathan; political theology; Presbyterian

\section{Author}

Ben Jones

Rock Ethics Institute

Pennsylvania State University

Email: btj7@psu.edu 


\section{Introduction}

A decade after Leviathan's publication, the event prompting it - the English Civil War-was over and the monarchy restored. As controversy continued to surround Leviathan due to its religious views, Hobbes tried to explain to England's new king his reason for writing it. This explanation appears in a 1662 letter to Charles II, sometimes referred to as An Apology for Himself and His Writings. Here Hobbes stresses that the purpose of Leviathan was to correct pernicious interpretations of the kingdom of God:

It was written in a time when the pretence to Christ's kingdom was made use of for the most horrid actions that can be imagined; and it was in just indignation of that, that I desired to see the bottom of that doctrine of the kingdom of Christ, which divers ministers then preached for a pretence to their rebellion: which may reasonably extenuate, though not excuse the writing of it. ${ }^{1}$

It is significant that Hobbes describes his motivations in these terms. The letter reveals that, for Hobbes, a primary reason for writing Leviathan was to counter subversive interpretations of the kingdom of God - a point often absent from accounts of why he wrote it. ${ }^{2}$ Because of the vicious political acts pursued in the name of Christ's kingdom, he felt compelled to clarify this Christian doctrine, and Leviathan is the result.

Passages from Leviathan confirm that these concerns were at the forefront of Hobbes's mind when he wrote it, not simply a post hoc explanation for Charles. In the text, Hobbes writes: 'The greatest, and main abuse of Scripture, and to which almost all the rest are either consequent,

\footnotetext{
${ }^{1}$ Thomas Hobbes, Seven Philosophical Problems, in The English Works of Thomas Hobbes of Malmesbury (hereafter $E W$ ), vol. 7, ed. William Molesworth (London: Longman, Brown, Green, and Longmans, 1845 ), 5.

${ }^{2}$ Part of the reason why is that studies most likely to make this point - namely, those emphasizing Hobbes's interest in the kingdom of God - generally neglect his 1662 letter to Charles. See, e.g., J.G.A. Pocock, 'Time, History and Eschatology in the Thought of Thomas Hobbes', in Politics, Language, and Time: Essays on Political Thought and History (New York: Atheneum, 1971), 148-201; Joel Schwartz, 'Hobbes \& the Two Kingdoms of God', Polity 18, no. 1 (1985): 7-24; and Meirav Jones, "My Highest Priority Was to Absolve the Divine Laws": The Theory and Politics of Hobbes' Leviathan in a War of Religion', Political Studies 65, no. 1 (2017): 248-63. Studies on the reception to Leviathan and Hobbes's efforts to fend off charges of atheism give more attention to the 1662 letter. See, e.g., Philip Milton, 'Hobbes, Heresy and Lord Arlington', History of Political Thought 14, no. 4 (1993): 50146; Jon Parkin, Taming the Leviathan: The Reception of the Political and Religious Ideas of Thomas Hobbes in England 1640-1700 (New York: Cambridge University Press, 2008), 222-24; and Jon Parkin, 'Baiting the Bear: The Anglican Attack upon Hobbes in the later 1660s', History of Political Thought 34, no. 3 (2013): $421-58$.
} 
or subservient, is the wresting of it, to prove that the Kingdome of God, mentioned so often in the Scripture, is the present Church, or multitude of Christian men now living, or that being dead, are to rise again at the last day'. ${ }^{3}$ This passage and the letter to Charles show Hobbes's enduring concern over the doctrine of the kingdom of God being perverted for political ends. When sects claim to represent God's kingdom, they imply that ultimate authority rests with them, not the civil sovereign. This belief, Hobbes worries, inevitably leads to political turmoil.

As part of his efforts to counter such views, chapter 31 of Leviathan presents a twofold understanding of God's kingdom:

(1) The prophetic kingdom of God, which exists at two points in time-ancient Israel and after Christ's return — when God rules directly over a chosen people through his prophetic word; and

(2) The natural kingdom of God or kingdom of God by nature, where God rules not through prophecy but the law of nature. ${ }^{4}$

With the prophetic kingdom closed off at present, Hobbes points to Leviathan-states as the manifestation of God's current kingdom - the natural kingdom of God. It is an interpretation of God's kingdom that renders it compatible with, rather than a threat to, civil authority.

This article argues that Hobbes's interpretation departs from previous understandings of the natural kingdom of God and plays a key, often overlooked role in his political philosophy. Many interpreters characterize the kingdom of God as a metaphor for the Leviathan-state. ${ }^{5}$ A close reading of De Cive and Leviathan, however, reveals that Hobbes makes a more radical claim: civil commonwealths are the manifestation of a real, not metaphorical, kingdom of Godspecifically, the natural kingdom of God. Obscuring this point has been insufficient attention to

\footnotetext{
${ }^{3}$ Hobbes, Leviathan, ed. Noel Malcolm (Oxford: Oxford University Press, 2012), 3:960.

${ }^{4}$ Hobbes, Leviathan, 2:554-56.

5 See Bryan Garsten, 'Religion and Representation in Hobbes', in Leviathan, ed. Ian Shapiro (New Haven: Yale University Press, 2010), 539; Robin Douglass, "The Body Politic "is a fictitious body": Hobbes on Imagination and Fiction', Hobbes Studies 27, no. 2 (2014): 144; Meirav Jones, “"My Highest Priority Was to Absolve the Divine Laws" ', 255; and Alison McQueen, Political Realism in Apocalyptic Times (Cambridge: Cambridge University Press, 2018), 138.
} 
the concept of the natural kingdom of God before Hobbes. Only by uncovering its earlier meaning do the ways that Hobbes alters it come into view.

With that goal in mind, this article traces the intellectual history of the natural kingdom of God, locating its origins in Catholic thought. The concept appears in the Catechism of the Council of Trent and writings of the Catholic theologian Robert Bellarmine as one of three different forms that God's kingdom takes. In these contexts, God's kingdom of nature refers to all his creation. Next the article turns to why certain understandings of God's kingdom strike Hobbes as politically dangerous. In his view, the Catholic Church introduced the subversive belief that the church represents the kingdom of God and, as such, has authority in temporal matters. This belief migrated to Presbyterian theology, causing great upheaval during the English Civil War. After explaining this context, the article examines Hobbes's alternative understanding of God's kingdom, which includes the natural kingdom of God. In contrast to the concept's meaning in Catholic thought, Hobbes describes this natural kingdom as manifesting itself on earth as civil commonwealths. He is not, however, always consistent in describing the exact nature of this relationship. Sometimes Hobbes describes the natural kingdom of God as existing before the Leviathan-state, which then more fully realizes this kingdom. Elsewhere he suggests that the Leviathan-state serves necessary functions for bringing this kingdom into existence. The presence of both these views in Hobbes's writings, I argue, ultimately sheds insights into the priorities in his political thought.

\section{The natural kingdom of God before Hobbes}

Though Hobbes makes no mention of the natural kingdom of God in The Elements of Law, the concept appears in his next major political works, De Cive and Leviathan. Hobbes first mentions 
the term in chapter 15 of De Cive, 'De Regno Dei per naturam', and then in chapter 31 of Leviathan, 'The Kingdome of God by Nature' ('De Regno Dei Naturali' in the Latin edition). These chapters do not provide many clues on the concept's origins, since they never reference other texts using it. Hobbes does frequently mention biblical references to the kingdom of God (or Christ or heaven), and dedicates numerous sections of Leviathan to clarifying their meaning (e.g., chapters $31,35,40-44,47)$. But the specific term natural kingdom of God does not appear in scripture. Since Hobbes never identifies any origins for this term, it can give the impression that he coins it.

The term does not appear to have been in wide use when Hobbes wrote. A search of 'kingdom of God by nature' or 'natural kingdom of God' (and spelling variants) in Early English Books Online finds these terms in none of the over 130,000 texts in its collection, except for writings by Hobbes and contemporaries responding to Leviathan ${ }^{6}$ Notably, the concept also is missing from statements of Anglican and Presbyterian doctrine from the period. The Thirty-Nine Articles of the Church of England, a summary of its core doctrines finalized in 1571, make no mention of the natural kingdom of God or kingdom of God generally. ${ }^{7}$ The concept of the kingdom of God takes a more prominent role in doctrinal statements from the 1640s marked by Presbyterian influence - the Westminster Confession, Shorter Catechism, and Longer Catechism. But, like the Thirty-Nine Articles, these statements never mention the natural kingdom of God. When explaining the second petition of the Lord's Prayer ('Thy kingdom come'), the Shorter Catechism only refers to the kingdoms of grace and glory. 'In the second petition', the catechism

\footnotetext{
${ }^{6}$ Search of Early English Books Online, https://eebo.chadwyck.com/home, January 4, 2018. What appears before Hobbes's political writings is the term 'kingdom of nature' in the same typology for God's kingdom found in the Tridentine Catechism (discussed below). See, e.g., William Sparke, The Mystery of Godlinesse: A Generall Discourse of the Reason that Is in Christian Religion (Oxford, 1628), 43.

${ }^{7}$ Church of England, The Thirty-Nine Articles, in Creeds and Confessions of Faith in the Christian Tradition, ed. Jaroslav Pelikan and Valerie Hotchkiss (New Haven: Yale University Press, 2003), 2:526-40.
} 
reads, 'we pray, that Satan's kingdom may be destroyed; and that the kingdom of grace may be advanced, ourselves and others brought into it, and kept in it; and that the kingdom of glory may be hastened' ${ }^{8}$

The kingdoms of grace and glory also appear in explanations of God's kingdom in the Catechism of the Council of Trent, or Tridentine Catechism, from 1566. What this Catholic catechism contains - but drops out in the Westminster Catechism — is discussion of the kingdom of nature as a third form of God's kingdom. So before Hobbes, one can trace the concept of the natural kingdom of God back to Catholic thought.

When explaining the second petition of the Lord's Prayer, the Tridentine Catechism advances a threefold understanding of God's kingdom - namely, of nature, grace, and glory. The kingdom of nature refers to God's 'providence which rules over all things'. 9 In other words, the kingdom of nature is God's rule over all creation. The kingdom of God also can mean 'that special and singular providence by which God protects and watches over pious and holy men', which is the kingdom of grace. ${ }^{10}$ Whereas the kingdom of grace refers to God's rule over Christians in a fallen world, the kingdom of glory refers to God's perfect kingdom that will arrive with Christ's return. ${ }^{11}$

Importantly, this threefold understanding of God's kingdom never refers to civil commonwealths now on earth. Augustine's City of God perhaps best reflects this view in Catholic thought. For Augustine, no commonwealth represents the kingdom of God or what he calls the heavenly city: 'While this Heavenly City ... is on pilgrimage in this world she calls out

\footnotetext{
${ }^{8}$ Westminster Assembly, The Westminster Shorter Catechism, in Creeds and Confessions of Faith in the Christian Tradition, ed. Jaroslav Pelikan and Valerie Hotchkiss (New Haven: Yale University Press, 2003), 2:662.

${ }^{9}$ Council of Trent, The Catechism of the Council of Trent (New York: Joseph F. Wagner, 1934), 522.

${ }^{10}$ Council of Trent, The Catechism, 523.

${ }^{11}$ Council of Trent, The Catechism, 524-25.
} 
citizens from all nations and so collects a society of aliens, speaking all languages'. ${ }^{12}$ Prior to Christ's return, 'the two cities' — earthly and heavenly_ 'are intermingled'. ${ }^{13}$ This influential account of the heavenly city refuses to deify and equate earthly kingdoms with God's.

Not all have followed Augustine's approach. For instance, the Emperor Constantine's favorable treatment of Christians raised expectations that earthly and divine kingdoms would become one. ${ }^{14}$ But despite occasional bursts of enthusiasm for particular rulers, this view has remained a marginalized position in Catholic thought. ${ }^{15}$ The political realm's imperfections undermine claims that it represents God's perfect kingdom. The Tridentine Catechism avoids any such equivalency: regardless of what form God's kingdom takes—nature, grace, or glory—it cannot be reduced to a civil commonwealth.

Hobbes's references to the kingdom of God in Leviathan show his familiarity with earlier formulations of it. He reproduces the Westminster Shorter Catechism's twofold understanding of God's kingdom - the kingdoms of grace and glory - in chapter 35 on 'the Signification in Scripture of Kingdome of God'. He writes: 'The Kingdome of God in the Writings of Divines ... is taken most commonly for Eternall Felicity, after this life, in the Highest Heaven, which they also call the Kingdome of Glory; and sometimes for (the earnest of that felicity) Sanctification, which they terme the Kingdome of Grace'. ${ }^{16}$ Chapter 35 does not mention the kingdom of nature, but chapter 31 does. Though Hobbes's description of the natural kingdom of God departs from Catholic thought, his mention of a rarely used concept also found in the Tridentine Catechism suggests his familiarity with its account of God's kingdom.

\footnotetext{
${ }^{12}$ Augustine, City of God, trans. Henry Bettenson (New York: Penguin Books, 1972), 19.19.

${ }^{13}$ Augustine, City of God, 19.26.

${ }^{14}$ See Eusebius, In Praise of Constantine, trans. H.A. Drake (Berkeley: University of California Press, 1976).

${ }^{15}$ See Benedict Viviano, The Kingdom of God in History (Wilmington: Michael Glazier, 1988); and Catholic Church, Catechism of the Catholic Church (Washington, DC: United States Conference of Catholic Bishops, 2000), 676.

${ }^{16}$ Hobbes, Leviathan, 3:634.
} 
Moreover, Hobbes read Bellarmine, whose writings reference the typology for God's kingdom found in the Tridentine Catechism. After the Protestant Reformation, Bellarmine became the Catholic Church's leading theologian in countering Protestant beliefs. When explaining the second petition of the Lord's Prayer, Bellarmine closely follows the Tridentine Catechism and reproduces its threefold understanding of God's kingdom. ${ }^{17}$ Hobbes likely came across some of these references to the natural kingdom of God. After all, the detailed criticism of Bellarmine in chapter 42 of Leviathan makes clear that Hobbes studied his writings closely. ${ }^{18}$ This interest in Bellarmine provides further reason to believe that Hobbes was familiar with the Catholic understanding of God's kingdom.

\section{The root source of 'Darknesse in Religion'}

In his chapter on the natural kingdom of God in Leviathan, Hobbes begins by framing it as a guide to balancing one's obligations to God and the civil authority. He aims to chart a path that can 'avoyd both these Rocks' of either offending God through 'too much civill obedience' or transgressing 'the commandments of the Common-wealth' through 'feare of offending God'. ${ }^{19}$ By framing the chapter in this way, Hobbes raises a concern made explicit later in Leviathan: many understandings of God's kingdom fail to clarify our obligations and instead 'causeth ... great ... Darknesse in mens understanding' over whom to obey. ${ }^{20}$ Before we look at the understanding of God's kingdom developed by Hobbes, it first is helpful to examine what he is

\footnotetext{
${ }^{17}$ Robert Bellarmine, De bonis operibus in particulari, in Ven. Cardinalis Roberti Bellarmini Politiani S.J. Opera omnia (hereafter Opera omnia), vol. 6, ed. Justinus Fèvre (Paris: Vivès, 1873), 402; and Dichiarazione piu copiosa della dottrina cristiana, in Opera omnia, vol. 12 (1891), 298.

${ }^{18}$ See also James Hamilton, 'Hobbes's Study and the Hardwick Library', Journal of the History of Philosophy 16, no. 4 (1978): 445-53.

${ }^{19}$ Hobbes, Leviathan, 2:554.

${ }^{20}$ Hobbes, Leviathan, 3:960.
} 
reacting against. Doing so provides insights into his strategy for correcting dangerous interpretations of God's kingdom, as well as why he sees this task as so urgent.

Parts III and IV of Leviathan go through an extensive list of theological positions that Hobbes finds fault with. Out of all of them, he singles out misinterpretations of the kingdom of God as the 'greatest, and main abuse of Scripture, and to which almost all the rest are either consequent, or subservient'. ${ }^{21}$ Similarly, when listing those doctrines 'contrary to the Peaceable Societies of Mankind', he starts with the 'Error' that 'the present Church now Militant on Earth, is the Kingdome of God'. ${ }^{22}$ This view is at the core of what Hobbes condemns as 'Darknesse in Religion', which encourages disobedience to civil authority and rebellion. ${ }^{23}$

According to Hobbes, it is a dangerous mistake to understand God's kingdom as an earthly entity distinct from the civil commonwealth. The kingdom of God offers benefits, like eternal life, that exceed anything that an earthly commonwealth can provide. Churches and sects that claim to embody God's kingdom arrogate to themselves an authority with subversive ramifications. For once a church becomes perceived as God's kingdom on earth, its perceived power surpasses that of the civil authority, which dashes any hope of unified sovereignty and peace. As Hobbes observes, 'men that are once possessed of an opinion, that their obedience to the Soveraign Power, will bee more hurtfull to them, than their disobedience, will disobey the Laws, and thereby overthrow the Common-wealth, and introduce confusion, and Civill war'. ${ }^{24}$ Indeed, for Hobbes, the 'most frequent praetext of Sedition, and Civill Warre, in Christian Common-wealths' is perceived conflict between civil and divine commands. ${ }^{25}$

\footnotetext{
${ }^{21}$ Hobbes, Leviathan, 3:960.

${ }^{22}$ Hobbes, Leviathan, 3:1104.

${ }^{23}$ Hobbes, Leviathan, 3:1106.

${ }^{24}$ Hobbes, Leviathan, 3:850.

${ }^{25}$ Hobbes, Leviathan, 3:928.
} 
Clearly for Hobbes, debates over God's kingdom are not mere theological exercises but come with high political stakes. When people believe that the present church is the kingdom of God, those perpetrating the error reap for themselves 'worldly benefits', like the right to govern the church and commonwealth. ${ }^{26}$ The belief that one embodies God's kingdom ultimately leads to claims of both spiritual and temporal authority.

Hobbes identifies 'the Romane, and the Presbyterian Clergy' as the 'Authors ... of this Darknesse in Religion' that conflates the church with God's kingdom. ${ }^{27}$ Not coincidentally, Behemoth's opening discussion of the causes of the English Civil War mentions these groups first when listing those responsible for corrupting the people and disposing them to rebellion. ${ }^{28}$ On Hobbes's view, subversive interpretations of God's kingdom originated in the Catholic Church and spread to the Presbyterians and other sects, resulting in political upheaval.

When confronting the claim that the church represents the kingdom of God, Hobbes often focuses on its source, Catholic theology. That point is evident from Leviathan's longest chapter (42), which is dedicated to showing Bellarmine's errors, among them his interpretation of the kingdom of God. It is a shrewd strategy for persuading mostly Protestant readers in England. Hobbes undermines claims that the church represents God's kingdom by showing that this belief originates in a source that many of his readers reject— the Catholic Church.

In his rebuttal of Catholic doctrine, Hobbes focuses on Bellarmine because he makes 'as strongly as is possible' the case for the pope's 'Supreme Ecclesiasticall Power'. ${ }^{29}$ Compared to other defenders of papal authority, Bellarmine takes a moderate position, which is why Hobbes finds his arguments more compelling (while still rejecting them). Bellarmine denies that the pope

\footnotetext{
${ }^{26}$ Hobbes, Leviathan, 3:1104.

${ }^{27}$ Hobbes, Leviathan, 3:1106.

${ }^{28}$ Hobbes, Behemoth, ed. Ferdinand Tönnies (Chicago: Chicago University Press, 1990), 2-3.

${ }^{29}$ Hobbes, Leviathan, 3:866. See also Patricia Springborg, 'Thomas Hobbes and Cardinal Bellarmine: Leviathan and

"The Ghost of the Roman Empire", , History of Political Thought 16, no. 4 (1995): 503-31.
} 
has supreme temporal authority. Instead, his concept of potestas indirecta —'indirect power'provides the basis for the pope's authority to intervene in temporal matters. While granting civil sovereigns supreme temporal power, Bellarmine argues that the pope's supreme spiritual authority on earth grants him indirect power in temporal matters. This power permits political intervention when necessary to achieve spiritual ends, as Bellarmine explains: 'since the end of the spiritual government is the attaining of eternal life, which is the supreme and ultimate end to which all the other ends are subordinated, it is certainly necessary that every temporal authority be subjected and subordinated to the spiritual authority of the supreme ecclesiastical bishop' ${ }^{30}$ When souls are at stake, the pope's 'authority extends ... to temporal matters', even to the point of being able to depose sovereigns, argues Bellarmine. ${ }^{31}$

Given its political implications, Hobbes still finds this moderate interpretation of papal authority dangerous. He identifies Bellarmine's view that 'the present Kingdome of God [is] administered by the Pope' as one of the flaws in his account of papal authority. ${ }^{32}$ According to Bellarmine, Christ has an eternal and spiritual kingdom, whose vicar on earth is the pope until Christ's return. ${ }^{33}$ As the head of this spiritual kingdom, the pope possesses supreme spiritual authority on earth and indirect temporal power. But Hobbes calls this spiritual kingdom supposedly headed by the pope a sham: 'Spirituall Common-wealth there is none in this world: for it is the same thing with the Kingdome of Christ; which ... is not of this world; but shall be in the next world, at the Resurrection' ${ }^{34}$ Christ's kingdom has not yet come according to Hobbes, a view that deprives the pope of a spiritual kingdom to rule.

\footnotetext{
${ }^{30}$ Bellarmine, On the Temporal Power of the Pope. Against William Barclay, in On Temporal and Spiritual Authority, ed. and trans. Stefania Tutino (Indianapolis: Liberty Fund, 2012), 161.

${ }^{31}$ Bellarmine, On the Temporal Power of the Pope, 304. See also Stefania Tutino, Empire of Souls: Robert Bellarmine and the Christian Commonwealth (Oxford: Oxford University Press, 2010), 9-47.

${ }^{32}$ Hobbes, Leviathan, 3:976.

${ }^{33}$ Bellarmine, Controversia de summo Pontifice, in Opera omnia, vol. 2 (1870), 148-51.

${ }^{34}$ Hobbes, Leviathan, 3:918.
} 
Beyond its political ramifications, the Catholic Church's claim to embody God's kingdom also endangers individuals' spiritual well being, argues Hobbes. On the basis of his purported spiritual authority, the pope could command subjects to depose a king deemed heretical to safeguard their souls and protect them from false doctrines. For Hobbes, though, such a command has the opposite effect because it requires violating the laws of nature, which are God's laws. ${ }^{35}$ The principal law of nature, Hobbes stresses, is 'that we should not violate our Faith, that is, a commandement to obey our Civill Soveraigns ${ }^{36}$ Disobeying the sovereign puts one's salvation in jeopardy, since 'the Kingdome of Heaven is shut to ... the disobedient, or transgressors of the Law $\cdot{ }^{37}$ By encouraging rebellion, Catholic teaching on God's kingdom inflicts twofold harm: it makes individuals liable to earthly and heavenly punishments.

Hobbes also sees this dangerous interpretation of God's kingdom in Presbyterian theology. Few examples better illustrate what Hobbes loathes about Presbyterian theology than Scottish reformer Andrew Melville's speech to King James VI in 1596. In this famous challenge to James's spiritual authority, Melville declares that Christ gives authority over his kingdom to the church and its ministers, not the king:

[T] here is King James, the head of this commonwealth, and there is Christ Jesus, the King of the church, whose subject James the Sixth is, and of whose kingdom he is not a king, nor a lord, nor a head, but a member. Sir, those whom Christ has called and commanded to watch over his church, have power and authority from him to govern his spiritual kingdom both jointly and severally; the which no Christian king or prince should control and discharge, but fortify and assist; otherwise they are not faithful subjects of Christ and members of his church. ${ }^{38}$

\footnotetext{
${ }^{35}$ Hobbes, Leviathan, 3:922.

${ }^{36}$ Hobbes, Leviathan, 3:932.

${ }^{37}$ Hobbes, Leviathan, 3:930.

${ }^{38}$ Thomas M'Crie, Life of Andrew Melville, new ed. (Edinburgh: Blackwood, 1899), 181.
} 
Melville and other Presbyterians embraced a conception of Christ's spiritual kingdom that divided earthly sovereignty between church and king. For Hobbes, that view inevitably leads to political strife.

What occurred at the Westminster Assembly further explains why Hobbes singles out the Presbyterians for criticism. Hobbes calls the Assembly's actions, backed by Parliament, a 'crime' because they 'alter[ed] the Church-government ... without the King's authority'.39 Presbyterians' strength in Parliament during the Civil War — a fact Hobbes bemoans ${ }^{40}$ — was a key factor leading it to call this assembly of clergy to develop reforms for the Church of the England. Since Charles I refused to authorize it, many clergy supportive of the established doctrines and episcopal structure of the Church of England did not participate, and their absence only heightened Presbyterian influence. ${ }^{41}$ That influence is evident in the resulting Westminster Confession, which adopts the very position Hobbes warns against—-belief that the church is the kingdom of God. This confession from 1647 states: 'The visible church, which is also catholic or universal under the gospel (not confined to one nation as before under the law) ... is the kingdom of the Lord Jesus Christ'. ${ }^{42}$ For Hobbes, such teaching contains the seeds of rebellion because it locates supreme spiritual authority in an entity (the church) distinct from any 'one nation'. Similarly, the confession places in the hands of church 'officers the keys of the kingdom of heaven', giving them power over who can enter this kingdom. ${ }^{43}$ In Leviathan, Hobbes rejects this position, saying that the keys of the kingdom of heaven discussed in Matthew 16:19 belong to

\footnotetext{
${ }^{39}$ Hobbes, Considerations upon the Reputation, Loyalty, Manners, and Religion, of Thomas Hobbes, in EW, vol. 4, ed. William Molesworth (London: John Bohn, 1840), 418.

${ }^{40}$ Hobbes, Leviathan, 3:1226.

${ }^{41}$ For more on the history of the Westminster Assembly, see Robert Paul, The Assembly of the Lord: Politics and Religion in the Westminster Assembly and the 'Grand Debate' (Edinburgh: T. \& T. Clark, 1985).

${ }^{42}$ Westminster Assembly, The Westminster Confession of Faith, in Creeds and Confessions of Faith in the Christian Tradition, ed. Jaroslav Pelikan and Valerie Hotchkiss (New Haven: Yale University Press, 2003), 2:638.

${ }^{43}$ Westminster Assembly, The Westminster Confession of Faith, 2:644.
} 
'all Supreme Pastors', that is, 'all Christian Civill Soveraigns' ${ }^{44}$ If this awesome power rests with the church rather than the sovereign, Hobbes fears, people will give their ultimate loyalty to the former-a recipe for civil war.

So from Hobbes's perspective, Presbyterians used the Westminster Assembly to smuggle dangerous Catholic beliefs on God's kingdom into the Church of England. Presbyterians just differ from Catholics in their belief of who constitutes the true church. Hobbes cannot help but note the irony of Presbyterians, known for their anti-Catholic fervor, embracing Catholic teaching on the kingdom of God: '[I]n those places where the Presbytery took that Office, though many other Doctrines of the Church of Rome were forbidden to be taught; yet this Doctrine, that the Kingdome of Christ is already come, and that it began at the Resurrection of our Savior, was still retained'. Presbyterians retain this doctrine, adds Hobbes, 'to have a Soveraign Power over the People'. ${ }^{45}$ The allure of power keeps Presbyterians from rejecting what Hobbes identifies as the most pernicious Catholic doctrine.

Once unleashed into the political sphere, beliefs about representing the kingdom of God have the potential to spread and take various forms. Hobbes observed this development on full display during the English Civil War, as Presbyterian doctrines encouraged more extreme sects. This 'brood of their own hatching', writes Hobbes, became a 'dangerous ... enemy to the Presbyterians'. ${ }^{46}$ One such sect named by Hobbes, the Fifth Monarchy Men, pointed to the 1649 execution of Charles I as a sign of the imminent arrival of Christ's kingdom on earth, at which point they would rule as God's elect. ${ }^{47}$ In this way, groups used apocalyptic beliefs about the

\footnotetext{
${ }^{44}$ Hobbes, Leviathan, 3:872.

${ }^{45}$ Hobbes, Leviathan, 3:1106.

${ }^{46}$ Hobbes, Behemoth, 136.

${ }^{47}$ William Aspinwall, A Brief Description of the Fifth Monarchy Men (London, 1653). See also B.S. Capp, The Fifth Monarchy Men (London: Faber \& Faber, 1972).
} 
kingdom of God to challenge the sovereign's authority and claim it for themselves. ${ }^{48}$ As with the

Catholics and Presbyterians, Hobbes shows little sympathy for apocalyptic sects. ${ }^{49} \mathrm{He}$ calls the

Fifth Monarchy Men 'fanatics" ${ }^{50}$ and condemns them for promoting bloodshed and political

strife during the Civil War. ${ }^{51}$

In short, when writing and reflecting on English politics during the 1640s and 1650s,

Hobbes encounters an environment filled with competing claims over the kingdom of God—how

it manifests itself, when it will be fully realized, and most critically who represents it and thus

should have spiritual authority on earth. These claims often undermine civil authority, and in

Hobbes's view contributed to the war that engulfed England. ${ }^{52}$ He concludes that neutralizing

these challenges to the civil sovereign requires a different understanding of the kingdom of God,

one suited for promoting political stability rather than rebellion. Let's turn now to the alternative

developed by Hobbes.

\footnotetext{
${ }^{48}$ For more on apocalyptic beliefs during this period, see John Wilson, The Pulpit in Parliament: Puritanism during the English Civil Wars, 1640-1648 (Princeton: Princeton University Press, 1969); Christopher Hill, Antichrist in Seventeenth-Century England (Oxford: Oxford University Press, 1971); Katherine Firth, The Apocalyptic Tradition in Reformation Britain, 1530-1645 (Oxford: Oxford University Press, 1979); and B.S. Capp, 'The Political Dimension of Apocalyptic Thought', in The Apocalypse in English Renaissance Thought and Literature, ed. C.A. Patrides and Joseph Wittreich (Ithaca: Cornell University Press, 1984), 93-125.

${ }^{49}$ Hobbes had a longstanding aversion to apocalyptic prophecy. In his earliest political work, he dismisses those who attempt to predict the world's end as 'learned madmen'. See Hobbes, The Elements of Law, ed. Ferdinand Tönnies (Cambridge: Cambridge University Press, 1928), I.10.9.

${ }^{50}$ Hobbes, Behemoth, 136.

${ }^{51}$ Hobbes, Historia Ecclesiastica, ed. and trans. Patricia Springborg, Patricia Stablein, and Paul Wilson (Paris: Honoré Champion, 2008), lines 1557-62.

${ }^{52}$ Writing during the Restoration, Hobbes notes that pernicious understandings of spiritual authority also came to infect Anglican clergy: 'I see a relic still remaining of the venom of popish ambition, lurking in that seditious distinction and division between the power spiritual and civil... All bishops are not in every point like one another. Some ... are content to hold their authority from the King's letters patents.... Others will needs have somewhat more, of divine right, to govern ... not acknowledging their power from the King, but immediately from Christ'. See Hobbes, Considerations upon the Reputation, Loyalty, Manners, and Religion, of Thomas Hobbes, 432. For more on the rise of divine right arguments by Anglican bishops during the Restoration, see Jeffrey Collins, 'The Restoration Bishops and the Royal Supremacy', Church History 68, no. 3 (1999): 549-80.
} 


\section{Hobbes's understanding of the kingdom of God}

What stands out about Hobbes's conception of the kingdom of God is that it abandons existing typologies. The Tridentine and Westminster Catechisms distinguish the forms of God's kingdom based on whom God rules: all creation in the kingdom of nature, the church militant in the kingdom of grace, and the church triumphant (after Christ's return) in the kingdom of glory. In contrast, Hobbes develops his typology of God's kingdom based on how God communicates law to his subjects. Chapter 31 of Leviathan states: 'God declareth his Lawes three wayes; by the Dictates of Naturall Reason, by Revelation, and by the Voyce of some man.... From hence there ariseth a triple Word of God, Rational, Sensible, and Prophetique: to which Correspondeth a triple Hearing; Right Reason, Sense Supernaturall, and Faith'. After outlining these forms that God's word can take, Hobbes adds: 'As for Sense Supernaturall, which consisteth in Revelation, or Inspiration, there have not been any Universall Lawes so given, because God speaketh not in that manner'. ${ }^{53}$ Since God does not communicate universal laws through supernatural sense, the kingdom of God can take two forms corresponding to the ways he does communicate law, through reason and prophecy. So in contrast to the Tridentine and Westminster Catechisms, Hobbes attributes to God the following twofold kingdom: (1) the natural kingdom of God, where laws are communicated through reason; and (2) the prophetic kingdom of God (sometimes called the kingdom of God by pact), ${ }^{54}$ where laws are communicated through prophecy (see Table 1).

At present, possible manifestations of God's kingdom are further limited because God no longer communicates his laws through prophecy according to Hobbes, which precludes the prophetic kingdom of God. Hobbes's view on miracles leads to this conclusion. In the prophetic kingdom of God, 'the operation of Miracles ... procureth credibility' for the prophet who

\footnotetext{
${ }^{53}$ Hobbes, Leviathan, 2:556.

${ }^{54}$ Hobbes, Leviathan, 2:572, 3:636.
} 
delivers God's word as law. ${ }^{55}$ For Hobbes, performing a miracle is necessary for 'a true Prophet ... to be known'. ${ }^{56}$ But by declaring 'Miracles now cease', Hobbes concludes that 'we have no sign left, whereby to acknowledge the pretended Revelations, or Inspirations of any private man; nor obligation to give ear to any Doctrine, farther than it is conformable to the Holy Scriptures'. ${ }^{57}$ Without miracles, it is impossible to establish the truth of prophecy, and therefore prophecy cannot function as universal law and the prophetic kingdom of God cannot exist.

But such a kingdom did exist in the past. On Hobbes's reading of scripture, the prophetic kingdom of God began with God's covenant with Abraham to rule over the Jewish people. ${ }^{58}$ In this kingdom, 'God was King, and the High Priest was to be (after the death of Moses) his sole Viceroy, or Lieutenant'. ${ }^{59}$ The prophetic kingdom of God then ceased to exist when the Jews rejected God's direct rule and elected Saul king. ${ }^{60}$

This past kingdom of God was a 'Civill Kingdome', which will be 'restored by Christ', writes Hobbes. ${ }^{61}$ He describes Christ as 'both God that spake and the Prophet to whom he spake'. ${ }^{62}$ Since Christ is God and man, his future kingdom clearly fits Hobbes's definition of a prophetic kingdom of God — namely, one where God communicates his prophetic word as law through the 'Voyce of some man' ${ }^{63}$ Hobbes stresses that Christ's kingdom will be 'a reall, not a metaphoricall Kingdome' on earth. This kingdom has not yet come, which Hobbes takes as self-

\footnotetext{
${ }^{55}$ Hobbes, Leviathan, 2:556.

${ }^{56}$ Hobbes, Leviathan, 3:582.

${ }^{57}$ Hobbes, Leviathan, 3:584. See also Kinch Hoekstra, 'Disarming the Prophets: Thomas Hobbes and Predictive Power', Rivista di Storia della Filosofia 59, no. 1 (2004): 97-153.

${ }^{58}$ Hobbes, Leviathan, 3:636. Sometimes Hobbes says the prophetic kingdom started with Moses. See Hobbes, Leviathan, 3:976.

${ }^{59}$ Hobbes, Leviathan, 3:640.

${ }^{60}$ Hobbes, Leviathan, 3:644.

${ }^{61}$ Hobbes, Leviathan, 3:644.

${ }^{62}$ Hobbes, Leviathan, 3:688.

${ }^{63}$ Hobbes, Leviathan, 2:556.
} 
Table 1: Comparing Hobbes's understanding of God's kingdom with competing views

\begin{tabular}{|c|c|c|c|c|}
\hline & \multicolumn{4}{|c|}{ Conceptions of the kingdom of God } \\
\hline & $\begin{array}{c}\text { Kingdom of } \\
\text { nature/Natural } \\
\text { kingdom of God }\end{array}$ & Kingdom of grace & Kingdom of glory & $\begin{array}{c}\text { Prophetic kingdom } \\
\text { of God }\end{array}$ \\
\hline $\begin{array}{l}\text { Catechism of the } \\
\text { Council of Trent } \\
\text { (1566) } \\
\text { '[T]he words, } \\
\text { kingdom of God, } \\
\text { have a variety of } \\
\text { significations.... }\end{array}$ & $\begin{array}{l}\text { 'In their ordinary } \\
\text { sense ... the words, } \\
\text { kingdom of God, } \\
\text { signify not only that } \\
\text { power which God } \\
\text { possesses over all } \\
\text { men and over the } \\
\text { entire universe, but, } \\
\text { also, His providence } \\
\text { which rules and } \\
\text { governs all things.... }\end{array}$ & $\begin{array}{l}\text { '[Christ] reigns over } \\
\text { those who are } \\
\text { endowed with a } \\
\text { superior faith, hope } \\
\text { and charity, and } \\
\text { have yielded } \\
\text { themselves pure and } \\
\text { living members to } \\
\text { God. It is in these } \\
\text { that the kingdom of } \\
\text { God's grace is said } \\
\text { to consist.... }\end{array}$ & $\begin{array}{l}\text { '[T]he kingdom of } \\
\text { glory ... is } \\
\text { perfect.... Then shall } \\
\text { all that is defective } \\
\text { and unsuitable be } \\
\text { utterly removed ... } \\
\text { God Himself will } \\
\text { then reign in our } \\
\text { souls and bodies'. }\end{array}$ & NA \\
\hline $\begin{array}{l}\text { Westminster } \\
\text { Shorter } \\
\text { Catechism (1647) } \\
\text { 'In the second } \\
\text { petition, which is, } \\
\text { "Thy kingdom } \\
\text { come", we pray, } \\
\text { that Satan's } \\
\text { kingdom may be } \\
\text { destroyed; }\end{array}$ & NA & $\begin{array}{l}\text { 'and that the } \\
\text { kingdom of grace } \\
\text { may be advanced, } \\
\text { ourselves and others } \\
\text { brought into it, and } \\
\text { kept in it; }\end{array}$ & $\begin{array}{l}\text { 'and that the } \\
\text { kingdom of glory } \\
\text { may be hastened'. }\end{array}$ & NA \\
\hline $\begin{array}{l}\text { Leviathan (1651) } \\
\text { '[T]here may be } \\
\text { attributed to God, } \\
\text { a twofold } \\
\text { Kingdome... }\end{array}$ & $\begin{array}{l}\text { 'Naturall, wherein } \\
\text { he governeth as } \\
\text { many of Mankind as } \\
\text { acknowledge his } \\
\text { Providence, by the } \\
\text { naturall Dictates of } \\
\text { Right Reason; }\end{array}$ & NA & NA & $\begin{array}{l}\text { 'And Prophetique, } \\
\text { wherein ... he } \\
\text { governed [one } \\
\text { nation] ... not only } \\
\text { by natural Reason, } \\
\text { but by Positive } \\
\text { Lawes, which he } \\
\text { gave them by the } \\
\text { mouths of his holy } \\
\text { Prophets'. }\end{array}$ \\
\hline
\end{tabular}


evident from the second petition of the Lord's Prayer, 'Thy kingdom come' ${ }^{64}$ Christians pray for this prophetic kingdom of God to arrive, but for now it remains closed off to them.

Though Hobbes shuts the door on the prophetic kingdom of God at present, he shows the way to the natural kingdom of God. This kingdom is governed by the laws of nature, which anyone with reason can learn. ${ }^{65}$ When describing the natural kingdom of God, Hobbes rejects the Tridentine Catechism's view that this kingdom refers to God's rule over all creation:

$[\mathrm{T}] \mathrm{o}$ call this Power of God, which extendeth it selfe not onlely to Man, but also to Beasts, and Plants, and Bodies inanimate, by the name of Kingdome, is but a metaphoricall use of the word. For he onely is properly said to Raigne, that governs his Subjects, by his Word, and by promise of Rewards to those that obey it, and by threatning them with Punishment that obey it not. Subjects therefore in the Kingdome of God, are not Bodies Inanimate, nor creatures Irrationall; because they understand no Precepts as his. ${ }^{66}$

To reign, God must have subjects who understand his laws and the rewards and punishments tied to them. Due to this criterion, the natural kingdom of God is limited to human beings.

Hobbes further narrows the scope of the natural kingdom of God by excluding from it atheists and those who deny God's providence 'because they acknowledge no Word for his'.67 Those failing to recognize God's laws are not subjects but 'Enemies'. ${ }^{68}$ These restrictions leave only a subset of humanity in the natural kingdom of God - those believing in God. In this regard, Hobbes departs from Catholicism's more expansive view of God's natural kingdom.

Though atheists have no place in Hobbes's natural kingdom of God, it is a mistake to conclude that it is necessarily a Christian kingdom. In his natural kingdom, God communicates law through reason rather than prophecy. But reason alone cannot establish many Christian doctrines - including that most central for Hobbes, 'Jesus is the Christ'-based on revelation

\footnotetext{
${ }^{64}$ Hobbes, Leviathan, 3:642.

${ }^{65}$ Hobbes, Leviathan, 3:932.

${ }^{66}$ Hobbes, Leviathan, 2:554.

${ }^{67}$ Hobbes, Leviathan, 2:554.

${ }^{68}$ Hobbes, Leviathan, 2:556.
} 
preserved by the Christian tradition. Nothing in God's word contradicts reason but things in it are 'above Reason', notes Hobbes. ${ }^{69}$ Therefore, as he writes elsewhere, 'nature does not suggest to us that the Scripture is the law of God'. ${ }^{70}$

If reason does not lead automatically to the Christian faith, what does it say about worshipping God in his natural kingdom? For Hobbes, reason leads to belief in God, which provides an explanation of 'a First, and an Eternall cause of all things'. ${ }^{71}$ It also leads to recognition of God's authority in his natural kingdom and the obligation to obey and honor him due to his 'Irresistible Power'.$^{72}$ Reason therefore shows that God exists and demands worship, but exactly what God is and how to worship him are questions to which reason lacks direct, determinate answers. Instead, the laws of nature provide an indirect answer: an authoritative arbiter must resolve these questions to avoid confusion and conflict over worship. Hobbes argues that such an arbiter is found in the civil sovereign, whose temporal and spiritual authority extends to establishing laws on the proper manner of worshipping God. ${ }^{73}$

This solution makes room in the natural kingdom of God for practices at odds with standard Christian understandings of God's kingdom. A sovereign could command subjects to engage in idolatry, and they would be obligated to obey says Hobbes. ${ }^{74}$ Idolatry is consistent with the natural kingdom of God when the sovereign commands it. Since reason demands belief in God, there are some restrictions on what the sovereign can command. Atheism and pouring

\footnotetext{
${ }^{69}$ Hobbes, Leviathan, 3:576.

${ }^{70}$ Hobbes, An Answer to a Book Published by Dr. Bramhall, in EW, vol. 4 (London: John Bohn, 1840), 363.

${ }^{71}$ Hobbes, Leviathan, 2:166.

${ }^{72}$ Hobbes, Leviathan, 2:558. For more on this belief by Hobbes and its role in Protestant theology, see A.P. Martinich, 'Natural Sovereignty and Omnipotence in Hobbes's Leviathan', in Hobbes on Politics and Religion, ed. Laurens van Apeldoorn and Robin Douglass (New York: Cambridge University Press, 2018), 29-44.

${ }^{73}$ Hobbes, Leviathan, 2:570.

${ }^{74}$ Hobbes, Leviathan, 3:784.
} 
'insults upon God' are off limits in the natural kingdom of God. ${ }^{75}$ But these limits hardly make the implications of Hobbes's view less controversial. By giving the sovereign broad discretion over religion, Hobbes crafts a conception of God's kingdom where not only Christianity but also idolatry can flourish.

This aspect of the natural kingdom of God bolsters the civil sovereign's authority and fits with Hobbes's overall political philosophy, while also proving controversial. In Hobbes's natural kingdom of God, the gap between the divine and civil law largely disappears. The sovereign has wide latitude in determining what God's law commands, and can go so far as commanding idolatry, in which case subjects would have an obligation to obey. This possibility creates a jarring juxtaposition—idolatry in God's kingdom. Predictably, contemporary critics like John Bramhall take Hobbes to task for defending an understanding of God's kingdom that prioritizes obeying man over God. ${ }^{76}$ Hobbes certainly gives his readers plenty of fodder for reaching this conclusion. In Leviathan's chapter on the natural kingdom of God, he cites Acts 5:29-'It is better to obey God than man' — and advises that this precept 'hath place in the kingdome of God by pact, and not by Nature' ${ }^{77}$ This portrait of the natural kingdom of God places such emphasis on obeying the civil authorities that it raises the worry of pushing God to the side. Indeed, in his efforts to render the kingdom of God safe for politics, Hobbes leaves himself vulnerable to the criticism that he mangles it beyond recognition.

Debates over the kingdom of God in the 1640s and 1650s help explain his decision to formulate an alternative open to this risk. In response to the havoc encouraged by subversive

\footnotetext{
${ }^{75}$ Hobbes, On the Citizen, ed. and trans. Richard Tuck and Michael Silverthorne (Cambridge: Cambridge University Press, 1998), 15.18 .

${ }^{76}$ John Bramhall, The Catching of Leviathan, in The Collected Works of John Bramhall, vol. 4 (Oxford: John Henry Parker, 1844), 576. See also Edward Hyde, A Brief View and Survey of the Dangerous and Pernicious Errors to Church and State, in Mr. Hobbes's Book, Entitled Leviathan (Oxon: Rad. Bathurst, 1676), 185-94.

${ }^{77}$ Hobbes, Leviathan, 2:572.
} 
understandings of the kingdom of God, Hobbes looks to develop a view compatible with all aspects of the civil sovereign's authority. Toward that end, he eliminates opportunities in the natural kingdom of God for churches and sects to challenge the sovereign's religious commands, even those demanding idolatry.

\section{More than a metaphor}

Among Hobbes scholars, there is a tendency to overlook the Leviathan-state's connection to the natural kingdom of God and focus instead on its connection to the prophetic kingdom of God. As a result, they often reduce the relationship between God's kingdom and the Leviathan-state to a metaphor. Bryan Garsten writes that, for Hobbes, 'it was the kingdom of men that was "metaphorical": the metaphor was between the rule of man and the rule of God'. ${ }^{78}$ Robin Douglass also emphasizes parallels between God's kingdom and the Leviathan-state: 'Hobbes insisted that the kingdom of God on Earth will not return until the second coming of Christ, but the fiction that he cast of the mighty Leviathan might appear to be a close approximation. Ironically, men living under such a mortal God could be deceived into thinking that the kingdom of God has come'. ${ }^{79}$ Alison McQueen comes to a similar conclusion: 'The state that emerges [from the state of nature] is a secular mirror image of the Kingdom of Christ ${ }^{80}$ And, relatedly, Meirav Jones argues that the 'historical kingdom of God over Israel ... was utilized by Hobbes as a source of ideas not only about kingdoms of God, but about commonwealths more generally ${ }^{81}$ On all these accounts, the Leviathan-state has features resembling the prophetic

\footnotetext{
${ }^{78}$ Garsten, 'Religion and Representation in Hobbes', 539.

${ }^{79}$ Douglass, 'The Body Politic "is a fictitious body", 144.

${ }^{80}$ McQueen, Political Realism in Apocalyptic Times, 138.

${ }^{81}$ Jones, "My Highest Priority Was to Absolve the Divine Laws", 255.
} 
kingdom of God — either the historic kingdom of Israel or Christ's future kingdom — which is distinct from calling it the actual kingdom of God.

There are parallels between the Leviathan-state and what Hobbes understands as the prophetic kingdom of God. But accounts focused on these parallels prove incomplete, for they fail to recognize the more direct link between the Leviathan-state and natural kingdom of God. Importantly, Hobbes's account of the natural kingdom of God in De Cive and Leviathan identifies the Leviathan-state as a concrete form that God's present kingdom takes.

His description of worship in the natural kingdom of God illustrates this point. In the natural kingdom of God, argues Hobbes in Leviathan, 'Reason directeth not only to worship God in Secret; but also, and especially, in Publique, and in the sight of men. And this ... Publique Worship ... is to be Uniforme: For those actions that are done differently, by different men, cannot be said to be a Publique Worship'. ${ }^{82}$ De Cive explains why worship must be public and uniform in God's natural kingdom:

[I]f individuals followed their own reason in worshipping God, worshippers are so different from each other that they would judge each other's worship to be unseemly or even impious; and would not accept that the others were worshipping God at all. And therefore it would not be worship, and even the worship most agreeable to reason would not be worship, because the nature of worship is to be a sign of inward honour, but a thing is only a sign if it makes something known to others. ${ }^{83}$

Uniformity guarantees that acts intended to honor God are understood as such by others. Reason demands uniformity because, without it, individuals could not communicate signs of honor to God. Not surprisingly, Hobbes identifies the civil sovereign as the entity responsible for designating 'signes of Honour' that 'ought to be taken and used for such, by private men in their publique Worship'. ${ }^{84}$ Without civil laws governing worship, there would be disagreement over

\footnotetext{
${ }^{82}$ Hobbes, Leviathan, 2:570.

${ }^{83}$ Hobbes, On the Citizen, 15.17.

${ }^{84}$ Hobbes, Leviathan, 2:570.
} 
what constitutes a sign of honor to God and no public worship. Leviathan-states therefore carry out the key function of ensuring public worship in God's natural kingdom.

The Leviathan-state also interprets the law of this kingdom, that is, the law of nature. In Leviathan, Hobbes makes this point prior to his chapter on the natural kingdom of God: 'the Judge constituted by the Soveraign Authority' — or the sovereign itself, as the Latin edition adds - determines the 'Interpretation of the Law of Nature'. ${ }^{85}$ De Cive's chapter on the natural kingdom of God is even more explicit in placing this responsibility with the civil sovereign:

[T] he interpretation of natural laws, both sacred and secular, where God reigns through nature alone, depends on the authority of the commonwealth, i.e. of the man or council which has been granted sovereign power in the commonwealth; and whatever God commands, he commands through its voice. And, conversely, whatever commonwealths command both about the manner of worshipping God and about secular matters, is commanded by God. ${ }^{86}$

So in the natural kingdom of God, whatever the civil sovereign commands is what God commands, and vice versa. That strong claim by Hobbes makes clear that people experience the natural kingdom of God through the Leviathan-state, which directly communicates to them this kingdom's laws.

Hobbes's conception of the natural kingdom of God functions as a remedy to what he sees as dangerous understandings of God's kingdom. Catholic and Presbyterian conceptions of God's kingdom pit the divine and civil law against one another. This conflict stems from the belief that the church represents God's kingdom, a status that gives it spiritual authority. The consequent disputes over spiritual authority leave people confused about their obligations.

Hobbes solves this dilemma by crafting a conception of God's current kingdom that eliminates conflict between divine and civil commands. In Hobbes's natural kingdom of God, individuals obey God through obeying their earthly sovereigns in civil and religious matters. By bringing

\footnotetext{
${ }^{85}$ Hobbes, Leviathan, 2:430-31.

${ }^{86}$ Hobbes, On the Citizen, 15.17.
} 
God's kingdom and the Leviathan together in a unified whole, Hobbes aims to dispel the darkness in religion that causes political turmoil.

Notably, Hobbes's approach hangs onto the hope that, when properly understood, the doctrine of the kingdom of God can promote peace. He could have rejected that God's kingdom currently exists, and left it at that. That is, God's kingdom is a civil kingdom that existed in ancient Israel and will come again when Christ returns, which no one can predict. This interpretation neutralizes claims about representing God's kingdom, while avoiding criticisms associated with equating imperfect commonwealths to God's perfect kingdom. Yet Hobbes holds onto the tempting idea that God's kingdom exists now. This decision perhaps reflects the importance he places on redirecting rather than dismissing his audience's religious ideals. ${ }^{87}$ His reinterpretation of the natural kingdom of God certainly aligns with this strategy. When many were looking for God's kingdom, Hobbes said it was before them: by obeying the civil sovereign, the (natural) kingdom of God could be theirs.

\section{Inconsistency in Hobbes's accounts of the natural kingdom of God}

As above the textual evidence shows, Hobbes sees the Leviathan-state as a manifestation of the natural kingdom of God. Yet the exact nature of this relationship is not always clear from Hobbes's writings, and there are different ways to interpret the Leviathan:

(1) Supplementary component of the natural kingdom of God-i.e., the Leviathan-state more fully realizes this kingdom but is not necessary for its existence; or

(2) Constitutive component of the natural kingdom of God-i.e., the Leviathan-state is a necessary feature for this kingdom to exist

\footnotetext{
${ }^{87}$ See S.A. Lloyd, Ideals as Interests in Hobbes's Leviathan (Cambridge: Cambridge University Press, 1992).
} 
The first line of interpretation, defended by Howard Warrender, A.P. Martinich, and others, ${ }^{88}$ characterizes Hobbes's natural kingdom of God as existing since creation in both the state of nature and civil society. On this view, the civil sovereign interprets the law in God's natural kingdom if the Leviathan-state exists, but the natural kingdom of God and natural law governing it remain in place in the state of nature. So though the Leviathan-state plays an important role in the natural kingdom of God, it is always a supplementary role. In contrast, the second line of interpretation sees the Leviathan-state as serving functions so necessary for the natural kingdom of God that, without it, this kingdom cannot properly be said to exist. The Leviathan-state constitutes the natural kingdom of God; when the former dissolves, so does the latter.

There are passages to support both interpretations. In support of (1), Hobbes sometimes describes God's reign in his natural kingdom as being continuous. From 'the very Creation', he writes in Leviathan, 'God [has] ... reigned over all men naturally by his might'. ${ }^{89}$ This description stems from two positions held by Hobbes: God's authority in his natural kingdom is grounded in his irresistible power; ${ }^{90}$ and God always has had this power. ${ }^{91}$ If the natural kingdom of God continuously exists, at least since creation, that suggests its existence regardless of whether a civil commonwealth is in place.

In other places, though, Hobbes says that God's power alone is insufficient to establish his natural kingdom, which has implications that potentially support (2). For God to 'properly ... Raigne', says Hobbes, his subjects must clearly understand his laws. ${ }^{92}$ Leviathan's chapter on the natural kingdom of God states: 'To rule by Words, requires that such Words be manifestly

\footnotetext{
${ }^{88}$ Howard Warrender, The Political Philosophy of Hobbes: His Theory of Obligation (Oxford: Oxford University Press, 1957); A.P. Martinich, The Two Gods of Leviathan: Thomas Hobbes on Religion and Politics (Cambridge: Cambridge University Press, 1992); and Michael Byron, Submission and Subjection in Leviathan: Good Subjects in the Hobbesian Commonwealth (New York: Palgrave Macmillan, 2015).

${ }^{89}$ Hobbes, Leviathan, 3:634.

${ }^{90}$ Hobbes, Leviathan, 2:558.

${ }^{91}$ Hobbes, Leviathan, 3:642.

${ }^{92}$ Hobbes, Leviathan, 3:554.
} 
known; for else they are no Lawes: for to the nature of Lawes belongeth a sufficient and clear Promulgation, such as may take away the excuse of Ignorance ${ }^{93}$ In the prophetic kingdom of God, miracles make prophecy known as God's law. Supernatural signs are unnecessary in the natural kingdom of God because individuals can grasp its laws through reason alone. ${ }^{94}$ But though the law of nature should be manifestly known does not mean it $i s$. Self-interested interpretations of the law of nature create confusion over its meaning, making it 'of all Laws the most obscure'. ${ }^{95}$ In De Cive, Hobbes raises this concern when discussing the natural kingdom of God: ' $[\mathrm{A}] \mathrm{s}$ anyone may make a mistake in reasoning, and consequently men may hold conflicting opinions about most actions ... whom did God will to be the interpreter of right reason, i.e. of his laws?' Hobbes responds, as discussed above, that whatever God commands he commands through the civil sovereign's voice.$^{96}$ Similarly, in the Latin Leviathan, Hobbes notes that 'few ... know how to look into their own hearts and read [the natural law] written there', so instead they learn it 'from the written laws ${ }^{97}$ Given the risk of confusion over the law of nature, the civil sovereign must provide an authoritative interpretation that makes it manifestly known. Without the Leviathan-state, the law governing the natural kingdom of God - the law of naturelacks clarity. Hobbes has concerns whether a kingdom whose law is plagued by ambiguity is properly a kingdom. After all, if an essential function of government is interpreting law, and the entity responsible for that function is missing, does the government truly exist?

These competing views over how to interpret Hobbes's natural kingdom of God relate closely to disputes over his theory of obligation. If the natural kingdom of God also exists outside civil commonwealths, its law - the law of nature - remains in force and obligates in the

\footnotetext{
${ }^{93}$ Hobbes, Leviathan, 2:556.

${ }^{94}$ Hobbes, Leviathan, 2:454.

${ }^{95}$ Hobbes, Leviathan, 2:430.

${ }^{96}$ Hobbes, On the Citizen, 15.17.

${ }^{97}$ Hobbes, Leviathan, 3:1204.
} 
state of nature. ${ }^{98}$ If, on the other hand, the natural kingdom of God only exists where there is a civil sovereign to interpret its law, the natural law governing this kingdom fails to be in force and obligate in the state of nature. ${ }^{99}$

Interpreters sharply disagree over which of these two accounts is correct, partly due to ambiguities in Hobbes's descriptions of the law of nature. In Leviathan, Hobbes uses the term 'law' when enumerating the laws of nature and calls them 'Immutable and Eternal', ${ }^{100}$ which seems to suggest they are laws and always in effect. But after listing the laws of nature in chapter 15, Hobbes concludes with a statement marked by equivocation: 'These dictates of Reason, men use to call by the name of Lawes; but improperly: for they are but Conclusions, or Theorems concerning what conduceth to the conservation and defence of themselves.... But yet if we consider the same Theorems, as delivered in the word of God, that by right commandeth all things, then are they properly called Lawes'. ${ }^{101}$ Depending on which half of the passage is emphasized, it can count as evidence for either side of the debate over how to interpret the laws of nature in Hobbes's thought. ${ }^{102}$ Then in chapter 26 of Leviathan, Hobbes suggests that the laws of nature lack the force of law prior to the commonwealth. Discussing the relationship between the civil and natural law, Hobbes writes that the laws of nature are 'actually Lawes' only when 'a Common-wealth is once settled ... and not before' ${ }^{103}$

Such contradictory statements pose challenges for interpreters. Since these inconsistencies occur within a single work, even individual chapters, it makes little sense to

\footnotetext{
${ }^{98}$ For this view, see Warrender, The Political Philosophy of Hobbes; and Martinich, The Two Gods of Leviathan.

${ }^{99}$ For this view, see Gregory Kavka, Hobbesian Moral and Political Theory (Princeton: Princeton University Press, 1986), 341-42; Perez Zagorin, Hobbes and the Law of Nature (Princeton: Princeton University Press, 2009), 52; and John Deigh, 'Political Obligation', in The Oxford Handbook of Hobbes, ed. A.P. Martinich and Kinch Hoekstra (New York: Oxford University Press, 2016), 307-13.

${ }^{100}$ Hobbes, Leviathan, 2:240.

${ }^{101}$ Hobbes, Leviathan, 2:242.

${ }^{102}$ See Martinich, The Two Gods of Leviathan, 123-24; and Deigh, 'Political Obligation', 307-8.

${ }^{103}$ Hobbes, Leviathan, 2:418.
} 
explain them as stemming from developments in Hobbes's thought over time. With that path closed off, there is a tendency to argue that one interpretation is incompatible with Hobbes's overall political philosophy, and therefore must be rejected as his considered view. ${ }^{104}$ That approach, though, puts interpreters in the tenuous position of trying to explain away a host of passages contrary to whichever position they defend.

I would like to suggest that a more promising approach lies in examining how the coexistence of conflicting accounts of the natural kingdom of God and law of nature may advance Hobbes's overall project. Contradictions sometimes suggest carelessness, but they also can show where a thinker's priorities lie. When discussing the kingdom of God, on some points Hobbes wavers while on others he remains firm. With regards to the latter, he is most emphatic about stressing the dangers of the Catholic and Presbyterian doctrine of equating the church with God's kingdom. Hobbes develops an alternative in which the current form of God's kingdom is the natural kingdom of God. His inconsistent accounts of this kingdom suggest that he places a higher priority on persuading readers to reject the Catholic and Presbyterian view than on getting them to accept all the details of his alternative. Perhaps the natural kingdom of God exists in the state of nature, or perhaps it doesn't. Either view is compatible with the civil sovereign's authority over religious matters, and ultimately Hobbes makes some room for both in his political philosophy. What is important from his perspective is that, when civil subjects look for

\footnotetext{
${ }^{104}$ E.g., Martinich argues that Hobbes's natural kingdom of God exists and issues law outside civil commonwealths because otherwise the natural law would fail to obligate in the state of nature and nothing would compel individuals to keep their covenants - which is necessary to form a commonwealth. In other words, for Hobbes's political philosophy to get off the ground, the natural kingdom of God must exist and be a source of obligation in the state of nature. See Martinich, The Two Gods of Leviathan, 74-87. There are reasons to question this argument. First, strictly speaking, individuals in the state of nature could choose to cooperate and institute a sovereign even if they are not obligated to do so. Second, as discussed below, Hobbes believes that almost all commonwealths establish themselves through acquisition and force. Under those conditions, coercion and the desire for self-preservation compel individuals to submit to the victor and exit the state of nature. To explain this transition, it is unnecessary to claim that the law of nature obligates cooperation absent coercion from others.
} 
God's kingdom on earth, they look toward the Leviathan-state and recognize it as the entity that communicates God's commands.

This approach in describing God's kingdom reflects a common strategy in Hobbes's writings. As Kinch Hoekstra notes, Hobbes often is willing to appeal to different values and assumptions - even contradictory ones - in an effort to persuade a broad range of readers to accept those conclusions necessary for peace. ${ }^{105}$ For instance, Hobbes uses varied, sometimes inconsistent imagery when describing the state of nature. Rather than formulate an account of the state of nature consistent in all its details, he appears to place greater importance on using imagery that strikes fear in many different people and motivates them to obey the sovereign. ${ }^{106}$

A similar mindset appears to guide Hobbes's theory of obligation. Many have tried to explain what, according to Hobbes, propels individuals in the state of nature to overcome their distrust toward one another, cooperate, and institute a commonwealth. For Hobbes, though, explaining the details of this transition appears to have been a far less central concern. ${ }^{107}$ At the end of Leviathan, he notes that 'there is scarce a Common-wealth in the world, whose beginnings can in conscience be justified'. ${ }^{108}$ On his view, commonwealths almost always emerge by force and acquisition, not by individuals freely coming together to institute one. ${ }^{109}$ Coercive power is what allows people to exit the state of nature. ${ }^{110}$ This dim view regarding the prospects of instituting a commonwealth may help explain inconsistencies in his accounts of the law of nature. Determining whether this law obligates in the state of nature is not Hobbes's primary goal — it is persuading individuals that the civil law does obligate. Readers can take

\footnotetext{
105 Kinch Hoekstra, 'The End of Philosophy (The Case of Hobbes)', Proceedings of the Aristotelian Society 106 (2006): 59.

${ }^{106}$ See Ioannis Evrigenis, Images of Anarchy: The Rhetoric and Science of Hobbes's State of Nature (New York: Cambridge University Press, 2014).

${ }^{107}$ Hoekstra also makes this point. See Hoekstra, 'The End of Philosophy', 60-61.

${ }^{108}$ Hobbes, Leviathan, 3:1135.

${ }^{109}$ For his distinction between commonwealths by acquisition and institution, see Hobbes, Leviathan, 2:262.

${ }^{110}$ For Hobbes's application of this principle to the English Civil War, see Hobbes, Leviathan, 3:1133-34.
} 
different views on the law of nature's obligations outside the commonwealth, as long as they recognize their duty to obey the civil law. Rather than provide a detailed blueprint for instituting a commonwealth, Hobbes puts more emphasis on why subjects must preserve a commonwealth by obeying their civil sovereign. The Catholic and Presbyterian understandings of God's kingdom stand in the way of that goal for Hobbes, and thus he points his readers toward safer alternatives.

\section{Conclusion}

Hobbes wrote Leviathan deeply concerned about the doctrine of the kingdom of God being abused to justify rebellion. Neutralizing this danger required a new understanding of God's kingdom. Hobbes offers that in chapter 31 of Leviathan and chapter 15 of the earlier De Cive. In contrast to the prevailing view at the time, he closely identifies the natural kingdom of God—-the only form God's kingdom can now take, according to Hobbes-with the Leviathan-state. By making this connection, Hobbes reinterprets the kingdom of God so that it no longer divides subjects' loyalties. God's present kingdom is not distinct from the commonwealth but one with it. With this interpretation, Hobbes aims to transform the doctrine of the kingdom of God into one that bolsters the civil sovereign's authority and promotes peace. 